\title{
RECONSIDERING ETHICS IN THE TECTONICS OF ARCHITECTURE THROUGH THE TECTONICS OF BODIES IN LOVE Yonca HÜROL*
}

Received: 29.05.2013; Final Text: 07.10.2014

Keywords: Body; architectural tectonics; ethics; value.

1. Techne is an ancient Greek concept, which is usually translated as craft or art.
* Eastern Mediterranean University, Department of Architecture, Famagusta, NORTH CYPRUS.

\section{INTRODUCTION}

The concept of tectonics has always been dependent on the duality between technology and representation. Botticher (1852) acknowledged the tectonic duality between structure and cladding. Semper (1951), conversely, highlighted the role of the joint in tectonics within its four elements of earthwork, hearth, framework-roof and enclosing membrane. His approach promoted the essence of the presence of modern professions, materials and systems. Sekler (1965) distinguished structure and construction from tectonics, whereas Vallhonrat (1988) claimed that the requirement of tectonics has made an impact on structures and construction. Moreover, while Frampton $(1990,2001)$ saw tectonics as the poetics of construction, Oxman posited, in 2012, that contemporary digital architecture transformed tectonics into informed tectonics, thus suggesting a new materiality. Accordingly, information is perceived as a type of material (Cache, 2002). The intent of this article is to discuss the ways in which the relationship between technology and representation can exist in contemporary tectonics, including informed tectonics.

Since the arrival of modernity, tectonics has become a key concept in comprehending the architectural agenda. Hartoonian (1994) clearly determined that the main difference between the modern and the traditional concepts of techne (1) - closely related to the concept of tectonics - is the secularisation of the modern. According to Hartoonian, unlike ancient Greek architecture, modern architecture is opposed to using building structures for the purpose of religious representation. Nevertheless, the structure became the main contributor to the aesthetics of modern architecture because of its determining role in the form of buildings (Frascari, 1996). Conversely, post modernism can be perceived as an attempt to decrease the role of technology in the meaning of architecture by incorporating symbolism back into the structure. The post-modern era may also be an attempt to reduce secularity. After post-modernism, some 
architects continued to use the modern language, whereas some others reverted to the older symbolic language. At this point, Leatherbarrow and Mostafavi (2005) identified the tension between technology and representation in architectural tectonics. According to them, some architects were designing highly technological but meaningless buildings, whereas others were designing meaningful but technologically problematic buildings. Accordingly, they argued that the difficulty in achieving a satisfying relationship between technology and representation remains the basic problem of architectural tectonics at the beginning of the $21^{\text {st }}$ century.

The contemporary theory of tectonics is inclusive of and open to a certain range of value systems. Frampton (2001) includes both technologically advanced buildings and rather more representational buildings in his book Studies in Tectonic Culture: The Poetics of Construction in Nineteenth and Twentieth Century Architecture, combining all of these buildings under a singular concept of tectonics. By claiming that tectonics is an "aesthetic rather than technological category", he accepts that there cannot be any tectonics in which technology is more dominant than aesthetic considerations (Frampton, 2001, 4). Although Frampton asserts that the joint is the essential unit in architecture, his theory highlights aesthetic considerations rather than technical matters (Frampton, 1990, 2001). He also argues that a building is a-tectonic if "the expressive interaction of load and support in architecture is visually neglected" (Frampton, 2001, 20). Thus, it is technology that should be artistically used. However, according to Frampton (2001, 16-19), the ontology of tectonics is based on simultaneously achieving high quality uses of technology and aesthetics. In other words, if technology is used only to dress the building for aesthetic purposes, then the outcome can only be scenographic rather than ontological. It can be stated that Frampton`s value system of tectonics is open to a range of different approaches in which aesthetics is more dominant than technology and technology plays a considerable role in the actual quality of the building. He accepted that only the buildings within this range can be considered pieces of architecture.

The concepts of digital architecture, parametric design and emergent technologies appeared at the end of the $20^{\text {th }}$ century and the beginning of the $21^{\text {st }}$ century. The most striking characteristic of digital or informed tectonics (Oxman, 2012) is the way it breaks down the distance between engineering matheme and architectural aesthetics. From within a rather practical approach, it can be said that digital architecture and parametricism have surpassed the theoretical tension between technology and aesthetics (Schumacher, 2009; Woodbury, 2010; Hensel, Menges, Weinstock, 2010). In digital architecture, the engineering quality is equally dominant to the artistic quality, and digital technology is the medium employed for creating the aesthetics. The elements and processes of digital construction are different from those previously used (Mitchell, 1998; Gao, 2004) and are similar to the production processes of industrial design products (Liu and Lim, 2006). Accordingly, there can be robotic fabrication and variable property design. Spuybroek (2003), who highlighted the importance of form in digital architecture, found that digital architecture is rather pliable, thereby challenging the old duality between technology and representation with its digital materiality (Gramazio, Kohler and Oesterle, 2010).

As a consequence of the above discussion, it can be said that the tectonics discourse is a battlefield of continuously shifting and strongly contradictory value systems, which accounts for the tension between 
the matheme (the analytical) and the poetics (the artistic) (Badiou, 2005). Today, while some architects support technology and rationality, others support the artistic dimension of architecture against its connection to knowledge, and still others defend the possibility of achieving all of these qualities simultaneously. These different camps also represent the possible professional identities of architects.

The existence and resilience of these camps are evidence of the dominance of the ontological approach within the ethics of architectural tectonics. The critical approach could have created much greater diversity because of its dialectical nature, and, consequently, it may have eliminated the extreme positions (Adorno, 1994). As Deleuze and Guattari (1993) suggested in their philosophy, the only way out of such a thought trap is to leave that plane of thought and move to one that has a different set of rules. The early indications of the presence of another plane as such were found in feminist theorists by highlighting the effect of the human body on architectural tectonics. For example, Agrest (1988) defended the belief that it is the male body that affected architecture. However, the preference for the extreme positions within feminist theory indicates that many of these theorists still belong to the plane of ontologies rather than the plane of critical thought. In fact, the author who first began to relate in a more critical way the theory of architecture to the discourse of physical bodies was R. Sennett, who stated in his book "Flesh and Stone" that people's aesthetical expectations of their bodies are similar to their aesthetical expectations of architecture (Sennett, 1994). Frampton (2001, 11) also stated that "Man articulates the world through his body... The body articulates the world."

This paper goes a step further by revealing the presence of various value systems in practical architectural tectonics, which is accomplished by approaching tectonics in the same way that people approach the bodies of their lovers. Although the option of considering the bio-political power relations (Foucault, 1977-8) to define another set of values for architectural tectonics is viable, this paper focuses on the various and equally valid value systems of sensual love between human bodies. An analogy is drawn that compares the tension between materiality and meaning in architectural tectonics and the tension between materiality and meaning in human love. There are different types of love, such as minimalist love (such as in the Middle Ages) (Deleuze and Guattari, 1993) and queer love (Foucault, 1984), in which the mind does not dominate the body any more. Because can also be stated that every 'body' has its value system in love, the relationship between materiality and meaning in human love can be perceived as an ethical problem. Thus, the author of this article takes an ideological position by accepting the ethical demand of being inclusive, which means that the exclusion of " -1 " (as Deleuze and Guattari suggested) as any category is not acceptable. Only the particularities that discriminate the poor, women, lgbti (2) people, different nationalities or races, animals, etc. can be discriminated as the "-1". Thus, "-1" cannot be the rich, men, heterosexuals, a certain nationality or race. The multitude of all the discriminated groups should come together to resist against the real oppressors from all groups (Hardt and Negri, 2000, 2004). Accordingly, this article asserts that the relationship between materiality and meaning in architectural tectonics is a matter of ethics as well as politics and tries not to hurt the feelings of anybody. 
3. Pornography is seen as rather commercial and not artistic. perceive the relationship between the materiality and the meaning of his/ her lover, these options, with respect to architectural tectonics, provide a less conservative and more inclusive approach to the theory of tectonics, as presented in this paper. However, such a reflection can also be considered an attempt to develop a rather materialistic (even haptic) view of tectonics, a view that focuses on the role of materials, production, joints and details in architecture (Pallasmaa, 2005). This more inclusive approach to tectonics creates the possibility of handling and combining the tectonics of digital architecture with other types of architecture.

Artistic, non-pornographic literature (3) about bodies contains a rich collection of descriptions regarding the relationship between the materiality and the meaning of bodies in love. Marquis de Sade, G. Bataille and $\mathrm{C}$. Bukovsky are among the first who come to mind with regard to the issue of non-pornographic bodily relationships. However, because these authors highlight materiality more than meaning in their approach to the human body, their perspectives are not appropriate for the purposes of this article. Marquis de Sade created the characters of sadist and masochist against tyranny. The sadist character was ironical with the power/law, whilst the masochist character had a sense of humour against power/law. Thus the ethics behind Sade's relation to human bodies was a political one (Deleuze, 1991; Hanoff, 1999). Battaille recognises human body with all its dirt and faeces (Bataille, 1982) and brings in other meanings beyond the content of this article. His thoughts are dependent on the acceptance of the death of not only God but also man (Foucault, 1976, 261-78). Bukovsky wrote autobiographical novels and poems about sex, violence and alcohol to satirise the lives of affluent groups. He wrote honestly about his experiences and fantasies (Sounes, 1998). However, to develop a more critical and ethical approach, it is healthier to look for literature in which there is a richer variety between the materiality and the meaning of others' bodies.

Proust's famous seven volume novel $A$ la recherché $d u$ temps perdu (In Search of Lost Time) presents a rich variety of tectonic expressions that combine materiality and meaning about bodies in love in various ways.

Proust makes many tectonic expressions of human bodies, pieces of architecture, space and furniture, gardens, etc. The most meaningful descriptions of the human body in his work are related to Swan and Odette's love (Proust, 1913) and Marcel and Albertine's love. Because Marcel and Albertine's love combines a larger scala of materiality and meaning in the relationship, this article concentrates mainly on the descriptions of the tectonics of Marcel and Albertine's love, and it is assumed in this article that their differing approaches to each other's bodies contain a set of ethical value systems. These value systems are then reflected in the discourse on architectural tectonics to support the discussion on the ethics of architectural tectonics.

Proust has been studied extensively from a psychological perspective (Kristeva, 1996; Nicole, 2008) and from the perspective of literary critics. He has also been studied from an architectural point of view, especially with respect to his relationship with Ruskin's theory and the images of cathedrals and medieval architecture in his works (Finn, 1994, Raillard, 1991). According to Proust and Ruskin, nature does not contain anything as pure/clear as human ideas and thoughts (Proust, 2006). Proust was very much impressed by Ruskin's efforts to relate artistic aesthetics to nature (William, 2000). Ruskin tried to defend this relationship for a very long 
time; however, he finally gave up and accepted that the origin of art is the striking and clear ideas of human beings (Clark, 1991). Although this renunciation hurt Proust, he wished to be more inclusive and accepted the co-existence of these two opposing types of 'artistic impressions'. The first artistic impression is very much related to nature (rather ambiguous), whereas the other originates from striking the ideas of human beings (rather clear). In other words, Ruskin's two separate conceptions of art coexisted in a fragmented manner in Proust's aesthetics (Picherit, 2007).

Proust's way of observing objects has also been studied in the literature (Pettena, 1991; Hughes, 2008). However, any analogy between his various approaches to the human body and the ethics of architectural bodies has not been previously suggested.

Marcel Proust wrote $A$ la recherché $d u$ temps perdu (Remembrance of things past) during the last 17 years of his life, after his mother's death. The novel consists of seven volumes (3000 pages). These seven volumes contain detailed memories of Marcel's childhood (childhood love as the main theme), youth (containing the love of other couples and love with Albertine), mature ages (with and without Albertine) and old age (containing many memories). As understood from the name of the book, the book mainly addresses the concepts of time and remembrance. Proust presents his theories about remembrance in this book. Impressions of space are also a very important issue of this novel. Proust presents his impressions about natural environments, architectural works and the houses of people very frequently. These can be strikingly clear impressions or very detailed ambiguous expressions.

This novel has been recognised as one of the greatest literary works of the $19^{\text {th }}$ century. In addition, many contemporary philosophers have been inspired by this novel. For example, the index of Deleuze and Guattari's (1993) Capitalism and Schizophrenia can be checked to see how many times Proust's name was used in the book. Thus, it is thought by the author of this article that Proust's novel can be a good source to relate to contemporary architecture.

Although $A$ la recherché du temps perdu is not an autobiography of Proust, it does reflect his life. Based on this work, Kristeva (1996) concludes that Proust is excessively and intensely sensitive towards experience. This aspect of his work contributes to and enhances the value of analysing the change in Marcel's values during his relationship with Albertine. As many pages within the various volumes of the novel contain lengthy explanations about bodily relationship with Albertine, it is possible to identify the levels of materiality in Marcel and Albertine's relationship throughout its various stages.

Examining Albertine and Marcel's love in various scenes, materiality can be identified according to the descriptions of the body form (the body as a whole), the surfaces (of the skin) and/or the details (usually within the skin). However, it is not that easy to differentiate the many levels of meaning in the body. One of the main problems confronting the author of this article is how to construct a method for identifying the many different levels of meaning in Albertine`s body. For this purpose, Marcel and Albertine's love is divided into different phases: the initial phase, which was when they first laid eyes on each other; the flirting phase; the beginning of the love affair and the continuing of Marcel's love after Albertine's death. The most representative scene from each phase is then 
selected and analysed. The concept of bodily relationship with Albertine in each scene is defined, and the change in these concepts is used to define the change in the meaning of their relationship. Later, this set of concepts regarding their bodily relationship is categorised, and these categories are then reflected in the various approaches to architectural tectonics. Thus, the methodology used in this article includes an analysis of related literary works, the development of an analogy between tectonics in love and tectonics in architecture and a discussion of differing results.

\section{TYPES OF CONCEPTS INDICATING THE DIFFERENT LEVELS OF MEANING}

The term concept is used in many of the arts, including literature, poetry and architecture. The phrase architectural concept, which determines the basic tectonic qualities, explains the initial creative phase of an architectural design. Architectural concepts have been subject to extensive study (White, 1975, 10-28; Mc Ginty, 1979, 208-37). Once the architectural concept is developed, all of the later stages of the design and all other details are defined as parallel to this concept, further supporting and strengthening this concept. However, it is not possible to identify the level of meaning of Albertine's and Marcel's bodies solely with the help of architectural concepts.

Consistent with the initial concept is the main characteristic of visual arts and architecture, which distinguishes visual arts and architecture from nature. However, in poetry and literature, the issue of concept development is different. According to Benjamin (1996), conceptual poetry is based on deviations from the initial concept, and the way Proust uses language in his novels is based on a similar approach. In $A$ la recherché du temps perdu (In Search of Lost Time), Proust describes a technique for developing literary images: the rule of three adjectives. According to this rule, once any object is defined with the help of a strong adjective, this should be followed by two other adjectives that decrease the strength of the first one. Ruskin also defended that nothing in the world can be as pure as a human idea (Clark, 1991). Thus, by balancing the strength of the initial adjective, poetry is more closely connected to nature.

The types of deviations from the initial poetic concept can also vary. There can be rather small, witty deviations, which make people think and smile (Bergson, 1999), or there can be more striking deviations that are included for the purpose of creating stronger emotions. The process of creating deviations in concepts has similarities to establishing the rules of a game in which some repetitive actions take place. The rule of play may be set to have a certain type of deviation, either striking or witty. This action is then followed by the experience of selflessness within the intensity of the game (Sennett, 1977). Still, the unity is not compromised or lost because each deviation belongs to the same game. Thus, we have the unity in freedom. In this article, it is accepted that the strength of the deviation from the initial concept determines the depth of the meaning of the concept. Accordingly, while evaluating the level of meaning in the various scenes regarding the tectonics of Albertine's and Marcel's bodies, the differences between the three types of concepts are used: concepts without any deviation (corresponding to holistic aesthetic meaning), concepts with witty deviations (corresponding to intellectual meaning) and concepts with striking deviations (corresponding to passionate meaning). 


\section{SCENES REGARDING THE TECTONICS OF ALBERTINE'S AND MARCEL'S BODIES}

This article identifies five different scenes that describe Marcel and Albertine's love because their love contains of five different phases. Marcel's love grows deeper with each phase. Marcel first sees Albertine with a group of her friends and is attracted by all of the girls.

“...They were now quite near me. Although each was a type absolutely different from the others, they all had beauty; but to tell the truth I had seen them for so short a time, and without venturing to look them straight in the face, that I had not yet individualised any of them. Save one, whom her straight nose, her dark complexion pointed in contrast among the rest, like (in a renaissance picture of the Epiphany) a king of Arab cast, they were known to me only, one by a pair of eyes, hard, set and mocking; another by cheeks in which the pink had that coppery tint which makes one think of geraniums; and even of these points I had not yet indissolubly attached any one to one of these girls rather than to another; and when (according to the order in which their series met the eye, marvellous because the most different aspects came next one another, because all scales of colours were combined in it, but confused as a piece of music in which I should not have been able to isolate and identify at the moment of their passage the successive phrases, no sooner distinguished than forgotten) I saw emerge a pallid oval, black eyes, green eyes, I knew not if these were the same that had already charmed me a moment ago, I could not bring them home to any one girl whom I might thereby have set apart from the rest and so identified..." (Proust, 1919: 331)

The materiality of this scene is based mainly on the holistic aesthetic of the bodies of the girls as their moving bodies are perceived as one body. However, the surfaces of these bodies (the skin of the girls) and the details (such as the eyes of the girls) are also described. We can, therefore, more accurately state that Marcel is attracted by the multiplicity of the girls. The materiality of Marcel's relationship with these girls depends mainly on the holistic aesthetics and movement of their bodies, as he perceives the youth and general beauty of the girls. However, he also perceives the softness and the colour of their cheeks, which suggests that there is a certain level of visual hapticity (Pallasmaa, 2005) in this scene. The girls were not aware of Marcel during this scene. They were walking in a playful way and probably enjoying the attention of everybody around. The behaviours of Marcel and the girls do not differ from those of other young people and are not unexpected. The meaning within this scene is mainly dependent on the holistic aesthetic play of forms, which means that although materiality is certainly dominant, there is also a meaning beyond materiality.

Later, Marcel begins to flirt, especially with two of the girls, one of whom is Albertine. Albertine flirts with Marcel, as do some other girls, especially Andree. Within this scene, their play with a ring and how their hands engage within the flirt determine the materiality of the scene.

“.....Andrée warming her hands at the fire, they had, with the light behind them, the gilded transparency of two autumn leaves. But, plumper than these, the hands of Albertine would yield for a moment, then resist the pressure of the hand that clasped them, giving a sensation that was quite peculiar to themselves. The act of pressing Albertine's hand had a sensual sweetness which was in keeping somehow with the rosy, almost mauve colouring of her skin. That pressure seemed to allow you to penetrate into the girl's being, to plumb the depths of her senses, like the ringing sound of her laughter, indecent as may be the cooing of doves or certain animal cries. She was the sort of woman with whom shaking hands affords so 
much pleasure that one feels grateful to civilisation for having made of the handclasp a lawful act between young men and girls when they meet. If the arbitrary code of good manners had replaced the clasp of hands by some other gesture, I should have gazed, day after day, at the unattainable hands of Albertine with a curiosity to know the feel of them as ardent as was my curiosity to learn the savour of her cheeks." (Proust, 1919, 444)

The materiality of this scene is still based on the holistic aesthetic of bodies. However, Marcel now perceives, in particular, the physical and psychological intensity of Albertine. Albertine also responds to his actions. The hapticity in the materiality of this scene is greater in comparison to that of the first scene, as evidenced through the increase in the description of the surfaces (such as the transparency of the skin) and the details (such as the peculiar sensation of Albertine's hand) as well as through the touching and touch of the hands. Because there is still nothing that is unexpected or different from the usual behaviour of other people, the meaning contained within this scene can also be considered dependent on the holistic aesthetics of bodies. Although the meaning does not change much in its character, the materiality has increased compared to the previous scene.

In the third scene, Marcel and Albertine choose each other as lovers. Marcel chooses Albertine because she is tall and flat, much like a young boy. Albertine is not as demanding as Marcel. There is a scene herein where Marcel becomes fixed on the neck and cheeks of Albertine. Watt (2005) contends that Albertine`s neck, which Proust describes as similar to a swan, is in fact symbolically male.

“...I found Albertine in bed. Leaving her throat bare, her white nightgown altered the proportions of her face, which, flushed by being in bed or by her cold or by dinner, seemed pinker than before; I thought of the colours which I had had, a few hours earlier, displayed beside me, on the 'front,' the savour of which I was now at last to taste; her cheek was crossed obliquely by one of those long, dark, curling tresses, which, to please me, she had undone altogether. She looked at me and smiled. Beyond her, through the window, the valley lay bright beneath the moon. The sight of Albertine's bare throat, of those strangely vivid cheeks, had so intoxicated me (that is to say had placed the reality of the world for me no longer in nature, but in the torrent of my sensations which it was all I could do to keep within bounds), as to have destroyed the balance between the life, immense and indestructible, which circulated in my being, and the life of the universe, so puny in comparison..." (Proust, 1919, 455)

Because Marcel kisses the neck of Albertine and Albertine responds to his love with body language, the hapticity of the materiality of this scene is greater than that of the previous scenes. The description of surfaces (such as her bare throat) and other details (such as the curls of her hair) now becomes more dominant than the description of holistic bodies. However, by preferring a girl who looks like a boy, a new game, in which there is a deviation, is introduced because it is expected that an ordinary boy would prefer a more feminine girl. Because it is not that extraordinary to fall in love with taller and flatter girls, the deviation in this scene can be perceived as a witty deviation that has intellectual connections rather than passionate connections. Similarly, it is also not expected for a lesbian to prefer to fall in love with a boy. Because the deviation is based on the details of the bodies, knowing that $\mathrm{M}$. Proust was gay should not change the strength of this deviation, which is the reality of the novel (Painter, 1959). Marcel in Proust's novel was not gay. 
Within the same scene, there are pages of long descriptions of Albertine's cheeks and neck. After reading so many pages about Albertine's skin, the reader forgets Marcel's conception of their love and concentrates directly on the materiality of their bodies.

“...On other days her face, more sleek, caught and glued my desires to its varnished surface and prevented them from going any farther; unless I caught a sudden glimpse of her from the side, for her dull cheeks, like white wax on the surface, were visibly pink beneath, which made me anxious to kiss them, to reach that different tint which thus avoided my touch. At other times happiness bathed her cheeks with a clarity so mobile that the skin, grown fluid and vague, gave passage to a sort of stealthy and subcutaneous gaze, which made it appear to be of another colour but not of another substance than her eyes; sometimes, instinctively, when one looked at her face punctuated with tiny brown marks among which floated what were simply two larger, bluer stains, it was like looking at the egg of a goldfinchor often like an opalescent agate cut and polished in two places only, where, from the heart of the brown stone, shone like the transparent wings of a skyblue butterfly her eyes, those features in which the flesh becomes a mirror and gives us the illusion that it allows us, more than through the other parts of the body, to approach the soul..." (Proust, 1919, 467-8)

It is evident that there are more details here than in the previous scenes. In fact, it can be concluded that every word contributes to detail and to nothing else. The two bodies communicate with each other. Furthermore, although all of the details are interrelated to each other, there exists a continuous deviation of the details with respect to each other, which is different from having a single deviation with respect to the concept of bodies. Accordingly, materiality dominates without needing any support from the meaning of their relationship, but this does not mean that the relationship has no meaning.

In the fourth scene, Albertine and Marcel are already together. However, Marcel now understands that Albertine is a lesbian and becomes very jealous of all her friendships with both men and women.

“....my jealousy was not reincarnate in fresh people, I had enjoyed after the passing of my anguish an interval of calm. But with a chronic malady, the slightest pretext serves to revive it, as also with the vice of the person who is the cause of our jealousy the slightest opportunity may serve her to practise it anew (after a lull of chastity) with different people. I had managed to separate Albertine from her accomplices, and, by so doing, to exorcise my hallucinations; even if it was possible to make her forget people, to cut short her attachments, her sensual inclination was, itself also, chronic and was perhaps only waiting for an opportunity to afford itself an outlet..." (Proust, 1923, 16)

Because this scene concentrates primarily on feelings and the materiality is in the second plan, the materiality of this scene is more abstract than that of the previous scenes. Marcel cannot accept Albertine as she is. He prisons her. Further, the increase in the depth of Marcel`s love for Albertine after learning that she is a lesbian may be perceived as a striking deviation, thereby adding rather passionate meaning to their relationship, even though there is a conceptual difference in their relationship.

In the fifth scene, Albertine dies and Marcel falls into a deep grief that prevents him from ever falling in love again. This last love scene does not contain any materiality except the materiality found in the memory of Marcel. 
There are four main types of materiality within these five scenes. The presence of the multiplicity of bodies is dominant in the first scene. The hapticity in the perception of Albertine's body then increases in every succeeding scene. The third scene combines two types of materiality. Although there is a witty deviation in the concepts of Albertine's and Marcel's bodies, the materiality of this scene is based on surfaces and details rather than on holistic forms. There is a bodily communication between Marcel and Albertine during the second and third scenes. It is possible to conclude that the type of materiality changes when they think about each other and when they are closer to each other. The physical distance from which they see each other's bodies decreases gradually within the first three scenes. However, the materiality of Marcel's love decreases considerably in the fourth scene, and the fifth scene contains no materiality. This fourth scene corresponds to Albertine's desire for having free relationships with other people, especially women, and the fifth scene corresponds to her death. Thus, the bodily communication between Marcel and Albertine is disturbed during these two scenes.

The variation regarding the type of deviation in the concept of their love towards each other shows that the meaning of their love changes during the different stages of their relationship. Because there is no deviation from the initial concept, the concepts of the first two scenes contain only holistic aesthetic meaning. In contrast, the concept of the third scene, which contains a witty deviation, is infused with intellectual meaning. In addition, it is the third scene that contains lengthy passages of witty deviations in the details of bodily communication. Thus, a relationship exists between the highest materiality and the intellectual meaning. Conversely, the concepts within the fourth and fifth scenes contain striking deviations that contribute to passionate meanings. Marcel is deeply in love with Albertine, whilst Albertine searches for her freedom.

\section{POSSIBLE VALUE SYSTEMS FOR TECTONIC BODIES IN ARCHITECTURE}

The analysis of the bodily descriptions in Proust's novel suggests that the materiality of bodies can be based on various arrangements of form, surface materiality and details and that materiality is totally absent or ignored only if there is deep passionate meaning that is based on striking deviations from the initial concept. However, there is always a meaning. It can be said that the tectonics of the bodies of Albertine and Marcel presented four different meanings throughout their relationship.

1. The consistent meaning, which is related to holistic aesthetic forms. In this type of meaning, there is no deviation from the initial concept.

2. The moderately playful meaning, which is an outcome of intellectually valuable deviations. In this type of meaning, there are witty deviations from the initial concept.

3. The heavily playful meaning, which is an outcome of passionate deviations. In this type of meaning, there are striking deviations from the initial concept.

4. The heavily playful meaning, which is an outcome of continuous witty deviations in the perception of the material body. In this type of meaning, there is an intellectual meaning, which is deferred by the materiality of love. 
What causes the presence of these meanings when approaching tectonic bodies in architecture can be the play of the details in the initial concept, a shift in the initial concept, or the continuous and intense play of details with respect to each other.

Although the theory of architectural concepts and the theory of architectural tectonics do not contain the aforementioned meanings, all of these meanings, which can also be considered different modes of play, already exist in architecture. When Tschumi asked Rice to design a minimum structure with maximum transparency for the large glass surfaces of the Paris Science Museum, Rice, remaining consistent with the initial concept of Tschumi, applied mathematics extensively to design the details of the suspended glass surfaces. Rice (1994, 111-2), the founder of these systems, claimed that he was only trying to minimise the amount of structural material used and that he was not attempting to create any particular image. It was again Rice who designed the geometry and arrangement of the roof tiles over the thick shells of the Sydney Opera House (Rice, 1994; Rice and Dutton, 1995; Frampton, 2001). Accordingly, the details of the suspended glass systems and the perfection of the arrangement of the roof tiles of the Sydney Opera House have only abstract aesthetic meaning because they are consistent with the initial design concept.

Conversely, when Kahn said "the detail is the adoration of nature" (Frascari, 1996, 507), he should have further offered a witty and intellectual concept of play that mimics the dialectics in nature. For example, the water outlet details in his project for the Salk Institute, including the inclined slabs of its mechanical floors (Moe, 2008), created a new intellectual meaning in architecture. Ando's window details, which minimise the size of the mullions, also create modest deviations from the main concept of his projects (Frampton, 2001). Thus, it can be concluded that the intellectual approach to architectural tectonics existed during various periods of contemporary architecture.

The best examples of the striking types of deviations from the initial architectural concept exist in Mies van der Rohe's architecture. Mies was extremely playful when he covered the steel columns of the Barcelona Pavilion with chrome, thus representing the steel frame in its best possible way as the main design concept. He also hid the steel beams in the slabs for the same reason. When he shifted his steel beams from the axe of his steel columns, he was also passionately playing with the mathematical perfection of the actual concept of the steel frame (Leatherbarrow, Mostafavi, 2005; Frampton, 2001). Mies's architecture contains many striking deviations from the main architectural concept, and, again, it is the use of details that prepared the striking deviation from the initial concept. Fox $(2001,158)$ offers an interpretation of the role of such striking deviations in Mies' Cullinan Hall in Houston:

\footnotetext{
“....emancipatory modernist narratives are implicit in the oppositional pairings that Mies materialized in the architecture of Cullinan Hall: new versus old, construction versus decoration, fact versus symbol, disclosure versus concealment, transparent versus solid, light versus heavy, open versus closed, and democratically accessible versus exclusionary. These pairings materialize the emancipatory social role that modern architecture was represented as discharging in the 1950 's."
}

Nonetheless, because his buildings are the products of the rules of the same play, his designs maintain unity. 
It is also possible for the same architect to create different types of meanings among his/her different buildings. One of the best examples to this is Kahn. We have already noted that Khan followed the intellectual approach in his Salk Institute. However, the Dakka Parliament Building, designed to have haptic stone walls, is the product of another type of play. However, these walls contained large openings with pure geometric shapes. By deciding to have large openings with optic forms on the haptic stone clad surfaces of this building (Frampton, 2001), Kahn was being passionately playful.

The first two types of meaning in tectonics depend on the use of details that either parallel or deviate from the initial concept. Conversely, the third type of meaning in tectonics is based on a radical shift in the initial concept with the help of the intensive use of details, which can range between 1/20 to 1/1 in scale.

The fourth type of meaning differs from the first three because of its high intensity and continuity of deviations, which occur within the perceptions of the materiality. Thus, the initial concept, along with the importance of the whole story, loses its effect. As a result, the present time and present space become dominant due to their materiality, playfulness and intellectual meaning. The best architectural examples of such continuous deviations of detail with respect to each other can be found in digital architecture. Because all points depart from simple or complex geometrically recognised forms, every point in digital architecture is a detail and every point is mathematically defined as information (Deleuze, 1992). This makes finite element analysis of very complex forms possible (Oxman, 2012), and the details are the details of the form. Accordingly, there can be corrugated or rough surfaces, and all forms can be produced because all forms can be defined in digital architecture.

The architecture of Gehry, Eisenman, Hadid and Lynn are offered as examples of digital architecture. However, there is a great deal of research being conducted regarding industrial production techniques, which can also be used to produce digital architecture (Oxman, 2012). For example, it is possible to produce a 3D print-out of digital architecture, creating both full and partial productions of the surfaces within the design possible. As a consequence of the advancements, digital architecture may well become recognised as the beginning of the second wave in industrial architecture and lose its contact with starchitecture.

The continuous deviation of every point (detail) in digital architecture makes its appearance similar to the forms in nature. Conversely, however, it is also possible to simulate natural forms in the digital environment, as is the case in emergent technologies (Hensel, Menges, Weinstock, 2010).

Because meaning in architecture is always created through materiality, there cannot be any architecture wherein materiality is totally absent and meaning is raised to an extreme level of passion. Such passion without materiality is possible only through the play of words in poetry and literature.

\section{CONCLUSION}

Materiality and immateriality do not simply exclude each other. Marcel and Albertine's love in Proust's novel In Search of Lost Time demonstrates 
that even the last immaterial phase of their love is dependent on previous material phases.

Materiality is understandable to the mind unlike certain types of immateriality. Emotions, which are related to pleasure, are in our awareness because they do not contain any pain or traumatic effects. All types of pain freezes (or decreases) mental activity, and consequently, all human activity, including art and design. However, pleasure activates the mind, and this state of mind -ethos- renders people more powerful. As an understandable concept, materiality includes emotions in addition to bodies. Because materiality is connected to emotions, it cannot be directly related to unethical concepts.

Tectonics is a materialistic approach to architecture; it is the emotional dimensions of architecture as well as its bodily characteristics. Thus, it is not inclusive to describe architectural tectonics as more of an aesthetical category than a technological category. Instead, it is more inclusive to understand that the concept of tectonics is based on the simultaneous presence of an aesthetical meaning and technological concern.

Details determine the type of aesthetics/meaning/representation in the tectonic body and can affect the materiality involved in tectonics. Because the play of details affects both materiality and meaning in architecture, the separation between technology and aesthetics/representation/meaning is considered to be illusory.

Ignorance of the role of details may cause the exclusion of the role of materiality and the relationship between the dialectics of nature and design. Ignorance regarding the significant role of details on design may also result in the exclusion of the role of play in design and thus, it may also ignore the tectonic meaning. Because the inclusion of the play of details enables the discussion of the ethics of tectonics, it is better to include the role of details in the theory of tectonics to better represent the play of tectonics in contemporary architecture.

However, it should not be forgotten that ethics and politics are closely related due to the inclusive nature of ethics. However, aesthetics can hide many problems and requests for absolute freedom. Although ethics restricts action, it includes all actions except actions that bring harm to others. Thus, it is possible for architects to have a passionate relationship with their architectural projects and to ignore some requirements, thereby bringing harm to somebody, the nearby environment, nature, social environment, society, and historical environment, etc.

Unlike a witty approach, passion cannot simultaneously combine feelings and mind. Thus, passionate approaches, which are based on striking ideas, can be ignorant when ethics and architectural politics are concerned. However, ethics require the inclusion of passionate architectural approaches unless they bring harm to others.

\section{REFERENCES}

ADORNO, T. W. (1966) Negative Dialectics, trans. E. B. Ashton (1994), $2^{\text {nd }}$ Print, The Continuum Publishing Company, NY.

AGREST, D.I., (1988) Architecture from without: Body, logic and sex, Assemblage, (7) 28-41. 
BADIOU, A. (1998) Handbook of Inaesthetics, trans. A. Toscano, (2005), Stanford University Press, California.

BATAILLES, G. (1928) Story of the Eye, trans. J. Neugroschal (1982), Penguin Books, London.

BENJAMIN, W. (1996) The Concept of Criticism in German Romanticism, Selected Writings, (1) 1913-26, trans. D. Lachterman, H. Eiland, I. Balfour, Bellknap Press of Harvard University Press, London.

BERGSON, H. (1999 [1911]) Laughter: An Essay on the Meaning of the Comic, trans: C. Brereton, F. Rothwell, Green Integer, Los Angeles.

BOTTICHER, K. (1852) The tectonics of the Hellenes, Postdam.

CACHE, B. (2002) Gottfried Semper: Stereotomy, biology and geometry, Architectural Design (72) 28-33.

CLARK, K. (Ed.), (1991) Selected Writings of John Ruskin. 4th ed, Penguin Books, London.

DELEUZE, G. GUATTARI, F. (1993[1980]) A Thousand Plataeus; Capitalism and Schizophrenia, $4^{\text {th }}$ Print, University of Minnesota Press, Minneapolis.

DELEUZE, G. (1988) The Fold: Leibniz and the Baroque, trans. T. Conley (1992), The University of Minnesota Press, Minneapolis.

DELEUZE, G. (1991 [1967]) Coldness and Cruelty, Zone Books, NY.

FINN, M. (1994) The cathedral work - Proust and Medieval ArchitectureFrench-Fraisse Revue D Historie Litteraire de la France. 94(5) 883-4.

FOUCAULT, M. (1977-78) Security, Territory, Population: Lectures at the College de France, ed, M. Senellart, [http://www.scribd.com/ doc/7861907/Foucault] used on (1.6.2010)

FOUCAULT, M. (1976) Preface a la Transgression, Dits et Ecrits, Galimard, Paris; 261-78.

FOUCAULT, M. (1984) Von der Freundschaft Michel Foucault Im Gesprach, Merve Verlag Berlin.

FOX, S. (2001) Cullinan Hall: A Window on Modern Houston, J A E. 54(3) $158-66$.

FRAMPTON, K. (1990) Rappel a l'ordre: The case for the Tectonic, Architectural Design, (60). 19-25.

FRAMPTON, K. (2001) Studies in Tectonic Culture: The Poetics of Construction in Nineteenth and Twentieth Century Architecture, ed., J. Cava, The MIT Press, Cambridge, Massachusets.

FRASCARI, M. (1996) The tell-the-tail detail, Theorizing a new agenda for architecture - An anthology of architectural theory 1965-1995, ed., K. Nesbitt, Princeton Architectural Press, NY; 498-515.

GAO, W.P. (2004) Tectonics? A Case Study for a Digital Free-form Architecture, Proceedings of Computer Aided Architectural Design in Asia, Yonsei University Press, Seoul; 519-34.

GRAMAZIO, F., KOHLER, M., OESTERLE, S. (2010) Encoding Material, Architectural Design- The New Structuralism: Design, Engineering and Architectural Technologies, eds. R.E. Oxman, R.M. Oxman, John Wiley and Sons; $108-15$. 
GREGOTTI, V (1996) The exercise of detailing, Theorizing a new agenda for Architecture: an anthology of architecture theory 1965e1995, ed., K. Nesbitt, Princeton Architectural Press, NY, 494-7.

HARDT, M., NEGRI, T. (2000) Empire, Harvard University Press.

HARDT, M., NEGRİ, T. (2004) Multitude: War and Democracy in the age of Empire, Penguin Press, NY.

HARTOONIAN, G. (1994) Ontology of Construction, Cambridge University Press, NY.

HENAFF, M. (1999) Sade- The Invention of the Libertine Body, trans. X.Callahan., M.Hanoff, The University of Minnesota Press, Minneapolis.

HENSEL, M. MENGES, A., WEINSTOCK, M., (2010) Emergent technologies and design - Towards a biological paradigm for architecture, Routledge, NY.

HUGHES, E. (2008) The material object in the work of Marcel Proust, French Studies. 62(1) 94-5.

KRISTEVA, J. (1996) Time and Sense- Proust and the Experience of Literature, trans. R. Guberman, Columbia University Press, NY.

LEATHERBARROW , D., MOSTAFAVI, M. (2005) Surface Architecture, The MIT Press, Cambridge, Massachusets.

LIU, Y.T., LIM, C.K. (2006) New Tectonics: A Preliminary Framework Involving Classic and Digital Thinking, Design Studies, 27(3) 267-307.

MCGINTY, T. (1979) Concepts in Architecture, Introduction to Architecture, ed. Snyder, J. C., Catanese, A. J., McGraw Hill Book Company, NY; 208-37.

MITCHELL, W.J. (1998) Antitectonics: The poetics of Virtuality, The Virtual Dimension: Architecture, Representation and Crash Culture, ed. Beckman J., Princeton Architectural Press, NY; 205-17.

MOE, K. (2008) Extraordinary Performances at the Salk Institute for Biological Studies, JAE. 61(4) 17-24.

NICOLE, E. (2008) Proust and the divided self - Research: Melting pot of Experimental Psychology, French Review. 81(5) 1006-7.

OXMAN, R. (2012) Informed tectonics in Material based Design, Design Studies, 33(5) 427-55.

PAINTER, G.D. (1959) Marcel Proust: A Biography, Chatto and Windus, London.

PALLASMAA, J.U. (2005) The Eye of the Skin, John Wiley and Sons Ltd., GB.

PETTENA, G. (1991) Proust arm-chairs- architecture, art, design and more, Domus. (733) 15.

PICHERIT, H.G. (2007) The Imposibly Many Loves of Charles Swann: The Myth of Proustian Love and the Readers 'Impression' in Un Amor De Swann, Poetics Today 28(4). 619-52.

PROUST, M. (1913) In Search of Lost Time: Swann`s Way (Du cote de chez Swann) trans. C.K. Scott Moncrieff. [http://gutenberg.net.au] used on (1.6.2010) 
PROUST, M. (1919) A l'ombre des jeunes filles en fleurs, In Search of Lost Time: Within a Budding Grove, trans. C.K. Scott Moncrieff. [http:// gutenberg.net.au] used on (1.6.2010)

PROUST, M. (1923) La prisonniere, In Search of Lost Time: The Captive, trans. C.K. Scott Moncrieff. [http://gutenberg.net.au] used on (1.6.2010)

PROUST, M. (2006) Saint-Beuve'e Karşı. (Contre Sainte-Beuve), trans. R. Hakmen, Doğu Batı Yayınları, İstanbul.

RAILLARD, G. (1991) Proust and Medieval Architecture- French- Fraisse, Quinzaine Litteraire, (569) 7.

RICE, P. (1994) An Engineer Imagines, Artemis, London.

RICE, P., DUTTON, H. (1995) Structural Glass, E\&FN Spon, Chapman\&Hall. London.

SCHUMACHER, P. (2009) Parametricism - A New Global Style for Architecture and Urban Design, $A D$ (Digital Cities). 79(4) 14-23.

SEKLER, E.F. (1965) Structure, construction, tectonics, Structure in Art and in Science, eds. G. Kepes, G. Braziller, NY; 89-95.

SEMPER, G. (1951) The four elements of Architecture and Other Writings, Cambridge University Press, NY.

SENNETT, R. (1994) Flesh and Stone: The Body and the City in Western Civilization, Norton.

SENNETT, R. (1977) The Fall of the Public Man, Knopf.

SOUNES, H. (1998) Charles Bukowski: Locked in the Arms of a Crazy Life, Grove Press; 275.

SPUYBROEK, L. (2003) Textile Tectonics, The state of Architecture at the Beginning of the $21^{\text {st }}$ Century, eds. Tschumi, B., Cheng, I The Monacelli Press, NY; 102-3.

VALLHONRAT, C. (1988) Tectonics Considered: Between the presence and the absence of the artifice, Perspecta (24) 122-35.

WATT, A. (2005) The sign of the swan in Proust's `A la recherché du temps perdu', French Studies 59(3) 326-37.

WHITE, E. T. (1975) Concept Sourcebook, A Vocabulary of Architectural Forms, Architectural Media Ltd., Arizona.

WILLIAM, C. (2000) Marcel Proust: A Life, Yale University Press, New Haven.

WOODBURY, R. (2010) Elements of Parametric Design, Routlage, NY.

Alındı: 29.05.2013; Son Metin: 07.10.2014

Anahtar Sözcükler: Beden; mimari tektonik; etik; değer.

\section{MIMARIDE TEKTONİĞE DAİR ETIGĞIN AŞKTA BEDENLERIN TEKTONİĞİ ÜZERINNDEN YENIDEN ELE ALINMASI}

Çağdaş tektonik bünyesinde teknoloji ile temsil arasında gerçekleşmekte olan çelişki göstermektedir ki tektonik tasarımda etik birbirine muhalif yaklaşımlara dayanmaktadır. Benzer bir çelişkiye aşk ilişkisi içerisindeki 
tektonik bedenlerin biribirleri ile ilişkisinde de rastlanabilmekle birlikte, aşk ilişkisi maddesellik ve anlam arasında çok farklı düzenlemelere imkan tanımaktadır. Bu makale M. Proust'un "Kayıp Zamanın İzinde" isimli romanındaki Marcel ile Albertine arasındaki aşk ilişkisinin çeşitli aşamalarını maddesellik ve anlam ilişkisi açısından incelemekte ve elde ettiği sonuçları olası teknoloji ve temsil ilişkileri olarak mimari tektoniğe yansıtmaktadır. Bu yansıtma mimari tektoniğe ait değerlere farklı yaklaşımların ifade edilmesini ve tartışılmasını kolaylaştırmaktadır.

YONCA HÜROL; B.Arch, PhD.

Graduated from METU, Department of Architecture in 1984. Completed Ph.D in Gazi University, Department of Architecture in 1992. Became an assistant professor in this school, in the area of building science in 1993. Working for Eastern Mediterranean University, Department of Architecture since 1998. Became associate professor in 2007 and professor in 2013.yonca.al@emu.edu.tr 
